\title{
AUTHENTIC ASSESSMENT OF HINDUISM LEARNING IN ELEMENTARY SCHOOL \\ Oleh
}

\author{
I Ketut Sudarsana \\ Universitas Hindu Negeri I Gusti Bagus Sugriwa Denpasar \\ iketutsudarsana@uhnsugriwa.ac.id
}

Diterima 6 Maret 2021, direvisi 25 Maret 2021, diterbitkan 1 April 2021

\begin{abstract}
Abstrak
Tujuan penelitian ini adalah untuk mendeskripsikan penilaian otentik pembelajaran agama Hindu di sekolah dasar. Jenis penelitian yang digunakan adalah deskriptif kualitatif, dimana pengumpulan datanya menggunakan metode observasi, wawancara dan studi pustaka. Penilaian merupakan bagian integral dari pembelajaran secara keseluruhan. Kedudukan penilaian dalam desain pelaksanaan pembelajaran merupakan bagian dari tiga komponen utama pelaksanaan yaitu tujuan pembelajaran, kegiatan pembelajaran, dan penilaian hasil belajar. Hasil penelitian menunjukkan bahwa kegiatan pembelajaran dirancang untuk memenuhi tujuan pembelajaran yang ingin dicapai. Penilaian diperlukan untuk mengetahui tingkat keberhasilan dan pencapaian tujuan pembelajaran. Penilaian juga digunakan sebagai umpan balik untuk proses pembelajaran itu sendiri. Penilaian diperlukan agar tindakan korektif dapat dilakukan dalam proses pembelajaran. Salah satu ciri penilaian yang baik adalah terus menerus sehingga perbaikan dalam proses pembelajaran dapat terus dilakukan.
\end{abstract}

Kata kunci: Penilaian Otentik; Pembelajaran Hindu; Sekolah Dasar

\begin{abstract}
The purpose of this study was to describe the authentic assessment of Hindu religious learning in elementary schools. This type of research is qualitative descriptive, where data collection uses the method of observation, interviews and literature study. Assessment is an integral part of overall learning. The position of assessment in the design of the implementation of learning is part of the three main components of implementation, namely learning objectives, learning activities, and assessment of learning outcomes. The results showed that the learning activities were designed to meet the learning objectives that had to be achieved. Assessment is needed to determine the level of success and achievement of learning objectives. Assessment is also used as feedback for the learning process itself. Assessment is needed so that corrective action can be taken in the learning process. One of the characteristics of a good assessment is continuous so that improvements in the learning process can continue.
\end{abstract}

Keywords : Authentic Assessment; Hinduism Learning; Elementary School

\section{Introduction}


ADI WIDYA: Jurnal Pendidikan Dasar FAKULTAS DHARMA ACARYA UNIVERSITAS HINDU NEGERI
Volume. 6, Nomor 1 April 2021

ISSN: 2685-8312 (online)

ISSN: 2527-5445 (cetak

http://ejournal.ihdn.ac.id/index.php/AW

Evaluation of student learning outcomes is carried out by educators to continuously monitor the process, progress, and improvement of student learning outcomes (Article $58 \mathrm{Law}$ Number 20 of 2003 on the National Education System). Based on this statement, it is important for teachers to know, understand, and be able to carry out a good assessment process in accordance with the applicable curriculum. Since the Competency-Based Curriculum (KBK) in 2004, there are competency standards, basic competencies, and indicators that indicate the level of student achievement in the curriculum. To determine this achievement, assessment is not only performed to measure learning outcomes but also to assess the learning process that takes place in class. Therefore, the teacher as an educator should not only measure students from their learning outcomes but also based on the learning process.

In Indonesia, the assessment system used is a traditional assessment using objective tests. Traditional assessment is more appropriate to be used to measure products or learning outcomes. The learning process cannot be measured by traditional assessment. The use of traditional assessment is also important to measure the level of understanding. However, traditional assessments using objective tests cannot measure overall competency. In addition, the use of objective tests in assessment has weaknesses, one of which is the luck factor in choosing an answer.

Since the enactment of the Education Level Unit Curriculum (KTSP) in 2006, the learning approach used is contextual teaching and learning. There are three main focuses in developing competency-based curriculum, namely determining competency, developing syllabus, and developing assessment. The assessment component is believed to have a real impact on the success of learning competencies for students, so the assessment is now placed in an important position in a series of learning activities. The form and method of assessment in many ways have an important influence on the learning process, how teachers must learn and how students should learn, and therefore determine the achievement of competencies (Nurgiantoro, 2018). Therefore, an appropriate assessment is needed to find out the achievement of the objectives in contextual learning.

Authentic assessment is the most important channel as the use of authentic assessment will include the selection of the teaching materials and the teaching and learning model. Authentic assessment guides teaching and learning through the creation of various learning activities carried out by students during the teaching and learning process which contains character values. Authentic assessment provides a real picture of the students 'reading comprehension ability and shows the indicators of the students' character development (Abidin, 2012). In essence authentic assessment itself is a real assessment and in accordance with the actual abilities of children (Nurisman \& Syaodih, 2019).

The purpose of authentic assessment is to measure a variety of skills in various contexts that reflect situations in the real world where those skills are used. Authentic assessment can also be used to guarantee true information about the abilities or competencies of students. Real activities designed to solve problems, "The real world", students may need in professional life and require a combination of skills related to knowledge, skills and attitudes (Hayati, Halim, \& Yusrizal, 2016). Authentic assessment includes three domains of learning outcomes, namely the realm of attitude, skills, and knowledge (Delita, 2017). Mueller (Maryam, 2014) mentioned that authentic assessment needs to be performed for several reasons, namely (1) authentic assessment is a direct assessment of the abilities and competencies of students, (2) authentic assessment provides opportunities for students to construct learning outcomes, (3) authentic 
assessment integrates learning, teaching, and assessment activities, and (4) authentic assessment provides opportunities for students to demonstrate their diverse abilities.

Acroding Depdiknas, the contextual learning approach can be applied to all subjects such as Hinduism. Hinduism learning aims to raise sradha and bhakti of students to Ida Sang Hyang Widhi Wasa through training, appreciation, and practice of Hinduism, so students become dharmika Hindus and able to realize the lofty ideals of Moksartham Jagadita (Sudarsana, 2018). The objective of Hinduism learning is to form sudjana, susila, and subratha person who has social sensitivity in a broad sense. The objective of Hinduism learning is to realize jagadhita and moksa based on dharma (Wiana, 1997). Likewise, in the seminar on the interpretation of Hindu religion I - XV (1999: 24) aspects, the objectives of Hindusim learning are :

1. Forming asthakti human beings to Ida Sang Hyang Widhi Wasa/God Almighty

2. Instilling Hinduism into a belief and foundation of all activities in all aspects of life

3. Forming ethical and spiritual morals in accordance with the teachings of Hinduism

4. Aligning and balancing the implementation of Hinduism in society between tattwa, ethics, and ritual

Thus it can be concluded that the objective of Hindusim learning is to form personality, attitudes, mentality, and character in students. So that students are able to understand suputra, susila, subiartha, and astiti bhakti in religious social life. Therefore, the assessment must measure the performance of the four skills, not just the knowledge of students on Hinduism textbooks. Real performance assessment uses Authentic assessment. The authentic assessment focuses on performance in daily behavior and not only on knowledge.

Authentic assessment is recommended since KBK and KTSP implementation. Supposedly, authentic assessment is no longer a new assessment for teachers in Indonesia. In fact, in the 2013 curriculum, authentic assessment is more emphasized than traditional assessment. Ideally, authentic assessment has been implemented well in schools especially those who have used the 2013 Curriculum.

The development of authentic assessment models shows a low understanding of Hinduism subject teachers so that classroom learning is also not fully implemented. Assessments conducted by teachers are still focused on cognitive assessment rather than the daily behavior of students. Teachers also mostly do not use rubrics to assess student performance.

\section{Method}

This study used a qualitative approach with literature study. Literature study is carried out by collecting a number of books, magazines, leaflets on problems and objectives of research. Books are considered as a source of data that will be processed and analyzed by historians, literary, and language experts (Danial, E., \& Wasriah, 2009). Literature study is conducted by examining and comparing literature sources to obtain theoretical data. In addition, by using literature studies, authors can obtain information about expected research techniques, so that the study does not duplicate.

\section{Results and Discussion}

\section{Basic Concept of Authentic Assessment}


Authentic assessment is a process of collecting, reporting, and using information about student learning outcomes by applying assessment principles, ongoing implementation, authentic, accurate, and consistent evidence as public accountability (Kurikulum, 2009). Terminologically, authentic is a synonym of original, real or true, valid, or reliable. Authentic assessment includes three domains of learning outcomes, namely attitudes, skills, and knowledge. Conceptually, authentic assessment is significant compared to standardized multiple-choice tests (Kemendikbud, 2013), 2013). Based on this basis, the teacher can identify material that is worthy of continuing and for remedial.

Assessment in the 2013 curriculum refers to the Minister of Education Regulation Number 66 of 2013 on Education assessment standards. The purposes of authentic assessment, namely:

a. Assessment planning is in accordance with the competencies to be achieved and based on the principles of assessment,

b. Assessment is carried out professionally, openly, educatively, effectively, efficiently and in accordance with the socio-cultural context; and

c. Assessment reporting is conducted in an objective, accountable, and informative manner.

Authentic assessment is often described as an assessment on the development of students, because it focuses on the ability of students to study on the subject.

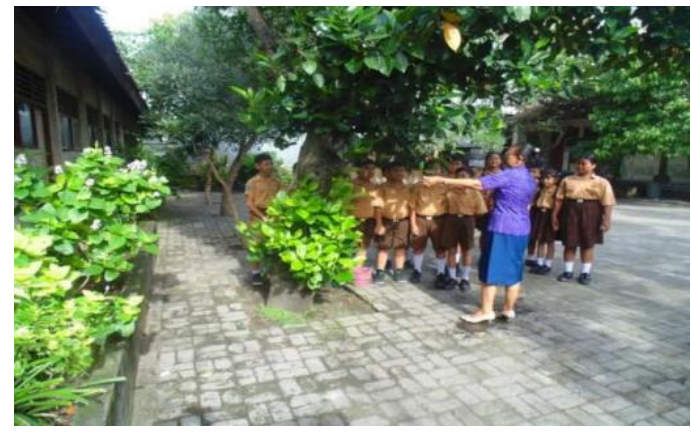

Figure 1 Learning Activities Outside the Classroom

Authentic assessment must be able to describe the attitudes, skills, and knowledge that students already have or do not have, how to apply knowledge, apply 1 earning outcomes, and so on. Authentic Assessment is a significant measurement of student learning outcomes for attitudes, skills, and knowledge. Authentic assessment is an assessment process that involves several forms of performance measurement that refl ect student learning, achievement, motivation, and attitude in accordance with learning material.

The elements of change and assessment in the 2013 curriculum can be seen in the following table (Kunandar, 2013).

\begin{tabular}{|c|c|}
\hline No. & Elements of Change \\
\hline 1 & Reinforce competency-based assessment \\
\hline
\end{tabular}




\begin{tabular}{|c|c|}
\hline 2 & $\begin{array}{l}\text { The shift from assessment through tests (measuring knowledge competencies based } \\
\text { on results only), to authentic assessments (measuring all competencies such as } \\
\text { attitudes, skills, and knowledge based on process and results) }\end{array}$ \\
\hline 3 & $\begin{array}{l}\text { Strengthening the PAP (Benchmark Assessment), namely achieving learning outcomes } \\
\text { based on the score obtained against the ideal score (maximum). This means that the } \\
\text { learning outcome of one student is not compared with other students, but is compared } \\
\text { with the minimum passing standard (KKM }\end{array}$ \\
\hline 4 & $\begin{array}{l}\text { Assessment is not only on basic competencies (KD) but also on core competencies (KI) } \\
\text { and the Graduate Competency Standard (SKL) }\end{array}$ \\
\hline 5 & Questions that do not have a single answer \\
\hline 6 & Encourage the use of portfolios made by students as the main instrument of assessment \\
\hline 7 & not just the \\
\hline
\end{tabular}

\section{Authentic Assessment Form}

\section{a. Performance Assessment}

Based on Kemendikbud, performance assessment is done by observing the activities of students in doing something. This assessment is suitable to be used to assess the achievement of competencies that require students to perform certain tasks such as: practice in the laboratory, praying, exercising, role-playing, playing an instrument, singing, and reciting (Delita, 2017). Performance assessment can be performed by using a checklist and rating scale. The checklist is used to find out the certain elements of the indicator or sub-indicator that appear in an event or action.

\section{b. Project Assessment}

Project assessment is an assessment of the tasks that must be completed by students according to a certain period of time. Kunandar (2013) stated that "assessment of a task includes collecting, organizing, evaluating, and presenting data". The task can be in the form of an investigation carried out by students, starting from planning, collecting, organizing, processing, analyzing, and presenting data. Thus, project assessment relates to aspects of understanding, applying, and investigating.

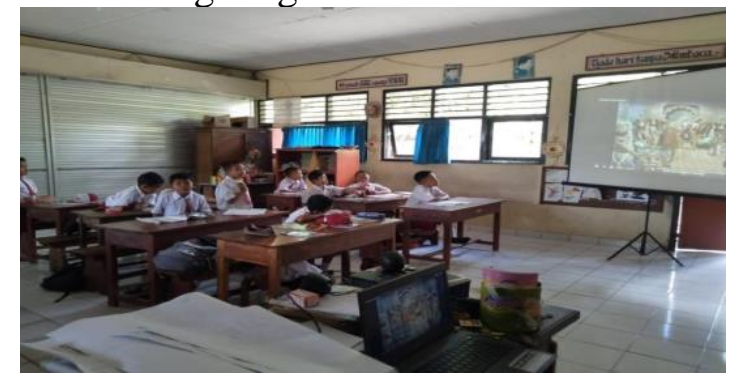

Figure 2 Teachers Using Audio Visual In Learning Hinduism

Project assessment is carried out starting from planning, working, until the final results of the project. For this reason, teachers need to determine the things or stages that need to be assessed, such as designing, collecting data, analyzing data, and preparing reports. Implementation of assessment can use assessment instruments in the form of checklist or scale. 


\section{c. Portfolio Assessment}

The portfolio assessment functions to assess the work of students individually or in groups based on several dimensions. The assessment portfolio in the classroom requires the following steps:

1) Explain to students that the use of a portfolio is not just a collection of work that is used for assessment. By looking at portfolios, the abilities, skills, and interests of students can be known.

2) Determine with students what portfolio samples will be made. Portfolios between one student and another can be the same but can also be different.

3) Collect and store the works of students in one folder at home or the student locker at school.

4) Give dates on each developmental information of students so the teacher can know the difference in quality from time to time.

5) Determine the criteria and weight of the portfolio assessment with students. Discuss ways of assessing the quality of works.

6) Ask students to evaluate the work on an ongoing basis. The teacher can guide the students on how to evaluate by giving information about the strengths and weaknesses of the work and how to improve it. This can be performed when discussing portfolios.

7) After work is assessed and but not yet satisfactory, students are given the opportunity to improve. However, between students and teachers there needs to be a "contract" or agreement regarding the period of correction, for example, within 2 weeks the corrected work must be submitted to the teacher.

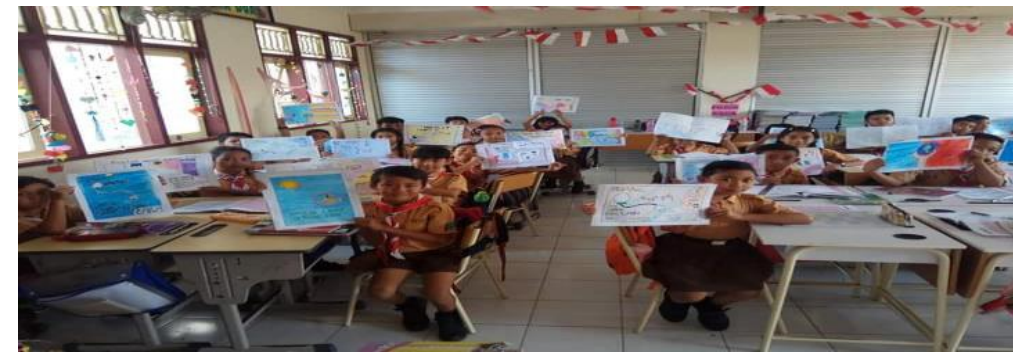

Figure 3 Students Doing Drawing Exercises

\section{d. Written Assessment}

Written assessment is still common. Written test with essay requires students to remember, understand, organize, apply, analyze, synthesize, evaluate, and so on the material learned. Written test with essay must be comprehensive so that it can describe the attitudes, skills, and knowledge of students. Written essay test requires two types of answers,

1) Extended-response

2) Restricted-response

It really depends on the weight of the questions given by the teacher. This test provides an opportunity for teachers to measure student learning outcomes at higher or more complex levels.

\section{e. Attitude Assessment}

Kunandar (2013) is divided into five levels of thought processes in the attitude domain, namely receiving or noticing, responding, evaluating or valuing, organizing or managing, and characterizing. Attitudes that need to be assessed in the learning process are:

1) Attitudes towards subjects.

2) Attitudes towards teachers/instructors 
3) Attitudes towards the learning process

The techniques used are behavioral observation, direct questions, and personal reports.

1) Behavioral Observation

2) Direct Question

3) Personal report

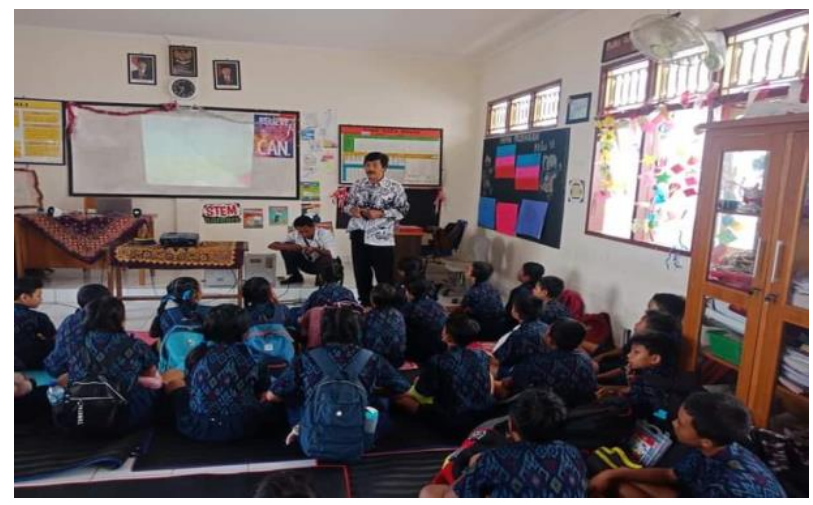

Figure 4 Teachers Encouraging Students Behaving Good

\section{f. Self-Assessment}

This technique can have a positive impact on personality development. Advantages of self-assessment in the classroom are:

1) Can foster self-confidence, because students are given the confidence to judge themselves;

2) Students are aware of their strengths and weaknesses because when conducting an assessment, they must make an introspection of their strengths and weaknesses;

3) Can encourage, accustom, and train to be honest, because students are required to be honest and objective in conducting assessments.

Self-assessment is based on clear and objective criteria. Therefore, self-assessment in class needs to be carried out through the following steps.

1) Determine the competency or ability aspects to be assessed.

2) Determine the assessment criteria to be used.

3) Formulate an assessment format, which can be in the form of scoring guidelines, a checklist, or a scale.

4) Ask students to do a self-assessment.

5) The teacher examines the sample assessment results, to encourage students to always carry out self-assessments carefully and objectively.

6) Give feedback to students based on assessment results taken randomly. 


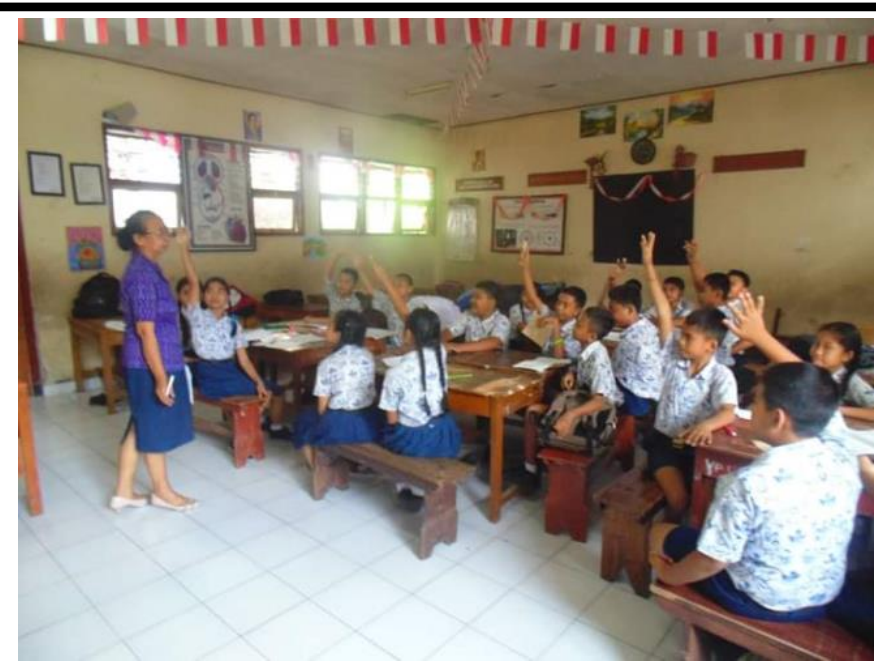

\section{g. Product assessment}

Figure 5 Learning Process In The Classroom

Product assessment uses holistic or analytic methods. The holistic method is based on the overall impression of the product. The analytic method is based on aspects of the product, usually carried out on all criteria at all stages of the development process by (Kunandar, 2013). There are several steps taken in designing authentic assessment, namely:

1) Choose one of the basic competencies from the topic of the subject

2) Identify the competencies for attitudes, knowledge, and skills in these basic competencies

3) Determine the type of authentic assessment that is in accordance with basic competencies.

4) Create an authentic assessment format based on basic competencies from the topic of the subject (see appendix: Minister of Education and Culture Regulation Number 104 of 2014 on Learning Outcomes Assessment by Educators in Elementary and Secondary Education)

5) Create assessment instruments on the attitudes, knowledge, and skills that will be used

6) Create a scoring guideline (rubric)

7) Use words, statements, or sentences according to indicators derived from basic competencies.

\section{CONCLUSION}

1. Authentic assessment is a process of collecting, reporting, and using information about student learning outcomes by applying assessment principles namely, continuous implementation, authentic, accurate, and consistent evidence as public accountability that encompasses the cognitive, affective, and psychomotor domains.

2. The form of authentic assessment includes performance assessment, project assessment, portfolio assessment, written assessment, attitude assessment, self-assessment, and product assessment.

\section{REFERENCES}


Abidin, Y. (2012). Model Penilaian Otentik Dalam Pembelajaran Membaca Pemahaman Beroreintasi Pendidikan Karakter. Jurnal Pendidikan Karakter, 2(2).

Danial, E., \& Wasriah, N. (2009). Metode Penulisan Karya Ilmiah. Bandung: Laboraturium Pendidikan Kewarganegaraan.

Delita, F. (2017). Penerapan Authentic Assesment Pada Mata Kuliah IPS Terpadu Semester Gasal Tahun Ajaran 2016/2017. JURNAL GEOGRAFI, 9(2).

Hayati, C., Halim, A., \& Yusrizal, Y. (2016). Pengembangan Dan Implementasi Perangkat Penilaian Otentik (Authentic Assessment) Dalam Pembelajaran Fisika di SMA N 4 Banda Aceh. Jurnal Pendidikan Sains Indonesia (Indonesian Journal of Science Education), 4(2).

Kemendikbud. (2013). Konsep Penilaan Autentik pada Proses dan Hasil Belajar. Jakarta: Modul Pelatihan Implementasi Kurikulum 2013.

Kunandar, D. (2013). Penilaian Autentik (Penilaian Hasil Belajar Peserta Didik Berdasarkan Kurikulum 2013). Jakarta: Raja Grafindo Persada.

Kurikulum, P. (2009). Pengembangan dan Pendidikan Budaya \& Karakter Bangsa. Jakarta: Depdiknas.

Maryam, S. (2014). Penerapan Penilaian Otentik Dalam Pembelajaran Bahasa Indonesia. Yogyakarta: Yogyakarta.

Nurgiantoro, B. (2018). Penilaian Otentik Dalam Pembelajaran Bahasa. Cakrawala Pendidikan, XXVII(3), 250-261.

Nurisman, D. K., \& Syaodih, E. (2019). Perencanaan Penilaian Otentik Kurikulum 2013: Jenis Jenis Penilaian Otentik. Edusentris, Jurnal Ilmu Pendidikan Dan Pengajaran, 4(3). https://doi.org/10.17509/edusentris.v4i3.378

Sudarsana, I. K. (2018). Pengantar Pendidikan Agama Hindu. osf.io. Retrieved from https://osf.io/preprints/inarxiv/35qkb/

Wiana, I. K. (1997). Cara Belajar Agama Hindu yang Baik. Denpasar: Pustaka Bali Post. 